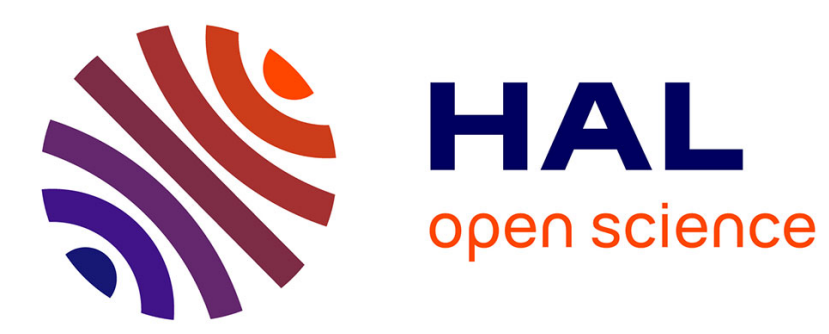

\title{
Cultured pituitary cell GtH response to GnRH at different stages of rainbow trout spermatogenesis and influence of steroid hormones
}

Claudine Weil, Odile Marcuzzi

\section{- To cite this version:}

Claudine Weil, Odile Marcuzzi. Cultured pituitary cell GtH response to GnRH at different stages of rainbow trout spermatogenesis and influence of steroid hormones. General and Comparative Endocrinology, 1990, 79, pp.492-498. 10.1016/0016-6480(90)90080-6 . hal-02712084

\section{HAL Id: hal-02712084 \\ https://hal.inrae.fr/hal-02712084}

Submitted on 1 Jun 2020

HAL is a multi-disciplinary open access archive for the deposit and dissemination of scientific research documents, whether they are published or not. The documents may come from teaching and research institutions in France or abroad, or from public or private research centers.
L'archive ouverte pluridisciplinaire HAL, est destinée au dépôt et à la diffusion de documents scientifiques de niveau recherche, publiés ou non, émanant des établissements d'enseignement et de recherche français ou étrangers, des laboratoires publics ou privés. 


\title{
Cultured Pituitary Cell GtH Response to GnRH at Different Stages of Rainbow Trout Spermatogenesis and Influence of Steroid Hormones ${ }^{1}$
}

\author{
C. WeIl AND O. MarcuzzI \\ Laboratoire de Physiologie des Poissons, INRA, Campus de Beaulieu, Rennes, France
}

Accepted October 27, 1989

\begin{abstract}
Using primary cultures of whole dispersed pituitary cells collected from rainbow trout at different stages of spermatogenesis, basal and $\mathrm{GnRH}$-induced $\mathrm{GtH}$ release and cell $\mathrm{GtH}$ content were studied in control and steroid-pretreated cultures. Steroid pretreatments were

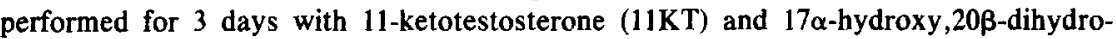
progesterone $(17 \alpha 20 \beta \mathrm{P})$ at levels corresponding to those circulating at the time of spermiation (50 and $20 \mathrm{ng} / \mathrm{ml}$, respectively). In control cultures, basal GtH release and cell GtH content increased with the stage of spermatogenesis in a characteristic pattern as predicted from in vivo results concerning plasma and pituitary GtH contents. The pituitary response to salmon $\mathrm{GnRH}$ ( $\mathrm{sGnRH}$ ) also varied as indicated by the decrease in the minimal effective dose of GnRH able to induce a significant $\mathrm{GtH}$ release with the advancement of spermatogenesis: $10^{-7} M$ at the spermatocyte stage, $10^{-9} M$ at prespermiation and spermiation. Steroid pretreatments were shown to have a direct effect on pituitary gonadotrophs and particularly on pituitary response to sGnRH, depending on the stage at which they are applied. At the beginning of spermatogenesis both of them induced an increase in GtH release and at prespermiation they have a slight negative effect, significant only with $17 \alpha 20 \beta$ P. At spermiation they have no effect except for $17 \alpha 20 \beta \mathrm{P}$ which increased the response to $10^{-8} M$ of sGnRH. Results are discussed in relation to hormonel changes (gonadotropin and steroid) observed by different authors during the sexual cycle. 11990 Academic Press, Inc.
\end{abstract}

Previously, we have studied in vivo the pituitary response to LHRH at different stages of spermatogenesis in intact (Weil et al., 1978) and castrated (Weil, 1981) rainbow trout. The response of intact fish to LHRH, characterized by the percentage of fish having a $\mathrm{GnRH}$-induced gonadotropin $(\mathrm{GtH})$ release, was absent at the beginning of spermatogenesis and increased during gonad maturation. In castrated fish, plasma $\mathrm{GtH}$ increased in comparison to controls as previously reported (Billard et al., 1976) whereas no change in pituitary responsiveness to LHRH was observed at prespermi-

${ }^{1}$ Presented in part as a poster at the Third International Symposium on Reproductive Physiology of Fish, St. John's, Newfoundland, Canada, 2-7 August 1987. ation and spermiation but it tended to increase at the beginning of spermatogenesis (Weil, 1981). We have now subjected primary pituitary cell cultures to $\mathrm{GnRH}$ action at various stages of spermatogenesis. In order to study the direct role of steroid hormones on pituitary, basal and GnRHinduced $\mathrm{GtH}$ release have been recorded after in vitro pretreatment with 11ketotestosterone (11KT) and $17 \alpha$-hydroxy, 20ß-dihydroprogesterone (17 $\alpha 20 \beta \mathrm{P})$, two major steroids at the time of spermiation (Campbell et al., 1980).

\section{MATERIALS AND METHODS}

\section{Animals}

Work was begun in June 1985 with males hatched from a fertilization performed in January 1983 with a winter-spawning strain reared at the Gournay/Aronde 
fish farm. Prior to use, fish were kept some months in the laboratory in a recirculated water unit at $12^{\circ}-13^{\circ}$.

Experiments were performed with fish at different stages of spermatogenesis. Spermiation was detected by stripping the fish; other stages were determined by macroscopic observation of the gonads using the criteria described by Billard and Escaffre (1975). The different stages studied were beginning of spermatogenesis (June 1985) and meiosis (July 1985), prespermiation (October 1985), and spermiation (January 1986 and March 1986).

\section{Pituitary Response to Salmon GnRH (sGnRH) in Control and Steroid-Pretreated Cultures}

Pituitary collection. At each defined stages of spermatogenesis, 10 to 30 animals were anesthetized with phenoxy-ethanol before pituitary removal, as described for females (Weil and Marcuzzi, 1990).

Cell cultures. Cultures were performed as described for such a study in females (Weil and Marcuzzi, 1990), using the technique previously set up for this species (Weil et al., 1986).

Control and steroid pretreatments. As soon as the cells were plated into the wells, the steroid and control pretreatments were applied for 3 days during cell attachment to the plastic according to Weil and Marcuzzi (1990).

The following steroids were tested:

$-11-$ ketotestosterone at a dose of $50 \mathrm{ng} / \mathrm{ml}$, which is the mean plasma level at the time of spermiation (Fostier et al., 1982).

$-17 \alpha$-hydroxy,20ß-dihydroprogesterone at a dose of $20 \mathrm{ng} / \mathrm{ml}$, which is the mean plasma level at the time of spermiation (Scott and Baynes, 1982).

Incubation with GnRH. On the third day of culture, control and steroid-pretreated wells were subjected to increasing doses of GnRH (0 to $10^{-\kappa} M$ ) during a 24-hr incubation period, as previously described (Weil and Marcuzzi, 1990).

\section{Data Analysis}

Parameters recorded. At each defined stage of spermatogenesis the following parameters were recorded in control and steroid-pretreated cultures:

-basal GtH release: GtH levels in wells without GnRH stimulation (dose 0 of GnRH).

_GnRH-induced GtH release for each tested dose. - pituitary GtH content in control and GnRHstimulated wells.

These parameters were estimated using a radioimmunoassay as previously described for assaying plasma and pituitary trout GtH content (Breton et al., 1983) and previously validated for $\mathrm{GtH}$ measurement in cells and culture medium (Weil et al., 1986). They were expressed in nanograms of $\mathrm{GtH}$ per well.

Statistical analysis. Means were compared by an analysis of variance or a nonparametric test (MannWhitney $U$ test). At each stage of spermatogenesis, the minimal effective dose of GnRH to induce GtH release was determined by comparing the mean GtH release using the Newman-Keuls test.

\section{RESULTS}

\section{Response to GnRH at Different Stages of Spermatogenesis}

At the beginning of spermatogenesis (spermatogonia A and B, GSI: $0.54 \pm$ $0.03 \%$ ), basal GtH release is low $2.00 \pm$ $0.86 \mathrm{ng} /$ well as well as $\mathrm{GnRH}$-induced GtH release; no significant increase was observed with the different doses of sGnRH, when compared with the basal level (Fig. 1).

When active spermatogenesis begins (presence of spermatocytes in all the fish and spermatids in some of them, GSI: 1.85 $\pm 0.23 \%$ ), basal GtH release is still low $(2.84 \pm 1.09 \mathrm{ng} / \mathrm{well})$. In contrast, gonadotrophs present in the culture are responsive to GnRH. Doses ranging from $10^{-9}$ to $10^{-7}$ $M$ induced a twofold increase compared to the basal level, at the limit of significance,

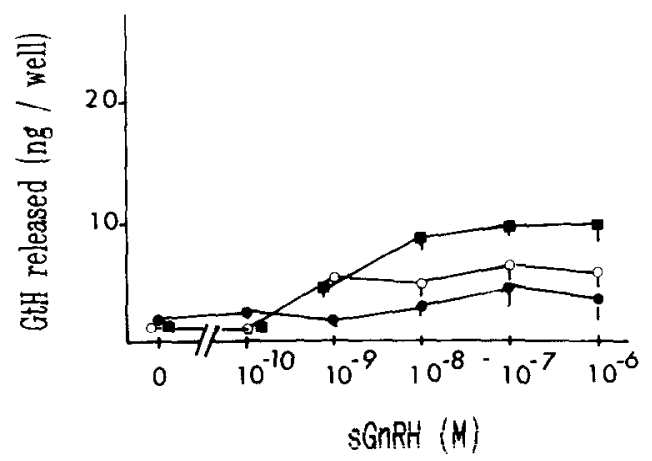

FIG. 1. Response to various doses of $s \mathrm{GnRH}$ of $\mathrm{pi}$ tuitary cell cultures from males at the beginning of spermatogenesis during a 24-hr incubation period, following a 3-day pretreatment in control medium (O) or in medium supplemented with $11 \mathrm{KT}, 50 \mathrm{ng} / \mathrm{ml}(\mathrm{O})$, or $17 \alpha 20 \beta P, 20 \mathrm{ng} / \mathrm{ml}$ ( $\square$ ). For this and subsequent figures wells were initially plated with $6.2 \times 10^{4}$ cells. Values are $\bar{x} \pm \operatorname{SEM}(n=5)$. 
whereas a significant 13.6 times increase $(P$ $<0.001$ ) was observed at the $10^{-6} M$ dose (Fig. 2).

At prespermiation (full spermatogenesis without spermiation, GSI: $4.67 \pm 0.39 \%$ ), basal GtH release was $5.72 \pm 0.83 \mathrm{ng} /$ well and the cells significantly $(P<0.025)$ responded to $10^{-9} M$ of sGnRH and the maximal increase for $10^{-7} M$ was 3.4 times the basal level (Fig. 3).

At spermiation (emission of spermatozoa, GSI: $3.29 \pm 0.24 \%$ ), basal GtH release was $10.51 \pm 1.77 \mathrm{ng} /$ well. Concerning responsiveness to $\mathrm{sGnRH}$ the minimal effective dose was $10^{-9} M$ and the maximal increase for $10^{-7} M$ of sGnRH was five times higher than the basal level, $P<0.001$, (Fig. 4).

Cell GtH content increased with the advancement of spermatogenesis, the highest values being recorded at the time of spermiation (Table 1).

\section{Influence of Steroid Pretreatments on Pituitary Response to sGnRH}

At the beginning of spermatogenesis

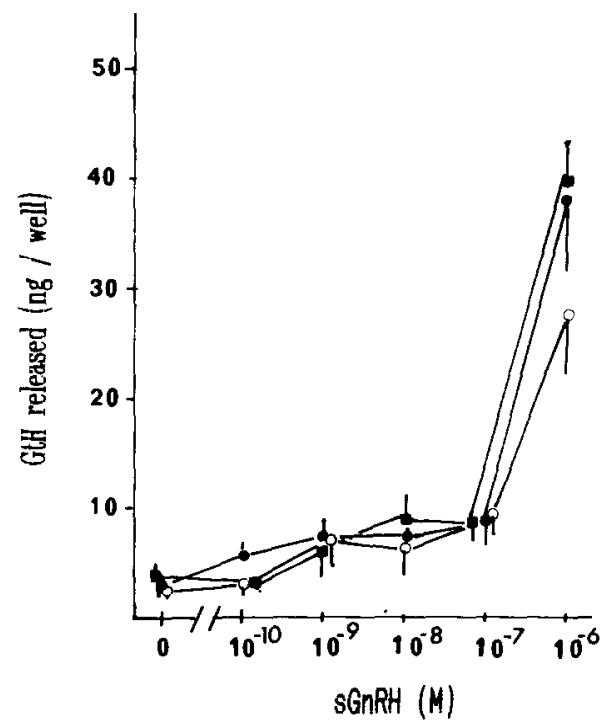

FIG. 2. Response of pituitary cultures from males at the meiosis stage to various doses of sGnRH during a 24-hr incubation period, following a 3-day pretreatment in control medium (O) or in medium supplemented with $11 \mathrm{KT}, 50 \mathrm{ng} / \mathrm{ml}(\bigcirc)$, or $17 \alpha 20 \beta \mathrm{P}, 20 \mathrm{ng} / \mathrm{ml}$ (ם). Values are $\bar{x} \pm \operatorname{SEM}(n=5)$.

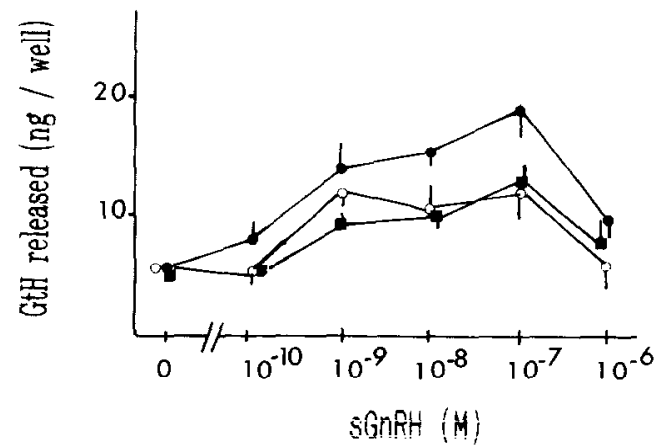

FIG. 3. Response of pituitary cell cultures from prespermiating males to various doses of sGnRH during a 24-hr incubation period, following a 3-day pretreatment in control medium (O) or in medium supplemented with $11 \mathrm{KT}, 50 \mathrm{ng} / \mathrm{ml}(\mathrm{O})$, or $17 \alpha 20 \beta \mathrm{P}, 20 \mathrm{ng} / \mathrm{ml}$ (a). Values are $\bar{x} \pm \operatorname{SEM}(n=5)$.

(spermatogonia A and B), a pretreatment of the pituitary cells with $11 \mathrm{KT}$ and $17 \alpha 20 \beta \mathrm{P}$ induced a significant increase $(P<0.05$ and $P<0.01$, respectively) in GnRH-induced GtH release when compared with control wells (Fig. 1), while cell GtH was unchanged (Table 1). These same pretreat-

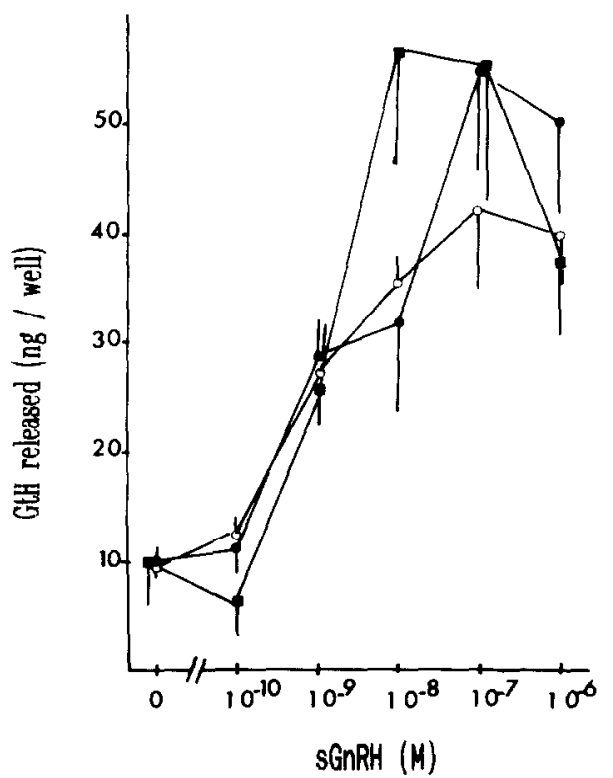

FIG. 4. Response of pituitary cultures from spermiating males to various doses of sGnRH during a 24-hr incubation period, following a 3-day pretreatment in control medium $(O)$ or in medium supplemented with $11 \mathrm{KT}, 50 \mathrm{ng} / \mathrm{ml}(\mathrm{O})$, or $17 \alpha 20 \beta \mathrm{P}, 20 \mathrm{ng} / \mathrm{ml}(\square)$. Values are $\bar{x} \pm \operatorname{SEM}(n=5)$. 
TABLE 1

Effect of Steroid Pretreatments on GtH Content of Pituitary Cell Cultures Set up with Males at Different Stages OF SPERMATOGENESIS

\begin{tabular}{clc} 
& \multicolumn{1}{c}{$\begin{array}{c}\text { Steroid } \\
\text { Stages }\end{array}$} & $\begin{array}{c}\text { Cell } \\
\text { GtH } \\
\text { content }^{c}\end{array}$ \\
\hline Beginning of & 0 & $66.51 \pm 15.15$ \\
spermatogenesis & $11 \mathrm{KT}^{a}$ & $79.23 \pm 16.49^{d}$ \\
Spermatocytes & $17 \alpha 20 \beta \mathrm{P}^{b}$ & $79.69 \pm 17.03^{d}$ \\
spermatids & 0 & $95.64 \pm 7.24$ \\
& $11 \mathrm{KT}$ & $106.40 \pm 12.14^{d}$ \\
Prespermiation & $17 \alpha 20 \beta \mathrm{P}$ & $97.11 \pm 5.85^{d}$ \\
& 0 & $174.15 \pm 3.87$ \\
Spermiation & $11 \mathrm{KT}$ & $145.53 \pm 9.07^{e, *}$ \\
& $17 \alpha 20 \beta \mathrm{P}$ & $154.13 \pm 13.85^{d}$ \\
& 0 & $550.62 \pm 51.07$ \\
& $11 \mathrm{KT}$ & $574.02 \pm 48.47^{d}$ \\
& $17 \alpha 20 \beta \mathrm{P}$ & $374.22 \pm 26.59^{e, * *}$
\end{tabular}

${ }^{a} 11$ Ketotestosterone, $50 \mathrm{ng} / \mathrm{ml}$.

b $17 \alpha$-Hydroxy,20 $\beta$-dihydroprogesterone, $20 \mathrm{ng} / \mathrm{ml}$.

${ }^{c}$ Values are $\bar{x} \pm$ SEM and expressed as nanograms per well

${ }^{d}$ Values not significantly different from control.

${ }^{e}$ Value significantly different from control $\left({ }^{*} P<0.008 ;{ }^{* *} P\right.$ $<0.16)$.

ments, applied to cultures set up with pituitary collected from males with gonads containing spermatocytes and spermatids, were without any effect on GnRH-induced $\mathrm{GtH}$ release (Fig. 2) and on cell GtH content (Table 1). At prespermiation, a decrease is observed in GnRH-induced GtH release following steroid pretreatment but it is significant $(P<0.05)$ only with $17 \alpha 20 \beta P$ (Fig. 3); on the other side $11 \mathrm{KT}$ induced a decrease $(P<0.08)$ in cell GtH content (Table 1). At spermiation, steroid pretreatment did not modify the response to sGnRH except 17 $\alpha 20 \beta$ P which increased $(P<0.05)$ the response to $10^{-8} M$ (Fig. 4) while cell GtH content was significantly $(P<0.016)$ decreased when compared with controls (Table 1).

\section{DISCUSSION}

We have studied, throughout the male rainbow trout sexual cycle, the response to sGnRH as well as basal and cell GtH content of the gonadotrophs present in pituitary primary cell cultures. The results in vitro are roughly in accordance with those previously obtained in vivo (Weil et al.,
1978) with intact fish. In vitro basal $\mathrm{GtH}$ level may be compared to the circulating GtH level and cell GtH content to pituitary GtH level; both of these parameters increased with the maturation of the testis. The response, respectively, to LHRH in vivo $(1 \mu \mathrm{g} / \mathrm{kg}$, administered by intracardiac injection) and to $\mathrm{sGnRH}$ in vitro (0 to $10^{-6}$ $M$ ) varied throughout the sexual cycle. In vivo, the response was undetectable at the beginning of spermatogenesis when low plasma and pituitary GtH levels were measured. In vitro, as well, no significant response was observed for all the tested doses of sGnRH and basal GtH level was low. The response began to appear in vivo in some fish when spermatocytes and spermatids were observed in the gonad and plasma $\mathrm{GtH}$ levels began to increase. At this stage, a response to GnRH was observed in vitro, an important increase being recorded, with the highest dose tested $\left(10^{-6} M\right)$. At the time of prespermiation and spermiation, some fish kept being responsive to LHRH in vivo with a kind of pulsatile secretion at the latter stage in both control and LHRH-treated fish. In vitro, at both stages the pituitary responded to a low dose of sGnRH $\left(10^{-9} \mathrm{M}\right)$ with a greater increase compared to the basal level at spermiation.

This variation in the response to $\mathrm{GnRH}$ could be due to changes in circulating steroid levels and in the present work, we have tested this hypothesis by studying the direct effect of $11 \mathrm{KT}$ and $17 \alpha 20 \beta \mathrm{P}$ on cultured pituitary cells pretreated for 3 days with either steroid. Both the plasma 11KT level (Scott and Baynes, 1982; Fostier et al., 1982, 1984; Baynes and Scott, 1985; Lou et al., 1986; Scott and Sumpter, 1989) and the $17 \alpha 20 \beta P$ level increase at the time of spermiation in rainbow trout (Scott and Baynes, 1982; Baynes and Scott, 1985; Lou et al., 1986; Scott and Sumpter, 1989). However, $11 \mathrm{KT}$ and $17 \alpha 20 \beta \mathrm{P}$ increases are out of phase, the first one peaking while the second one is just starting. These two steroids can act directly by increasing the re- 
sponse to sGnRH when applied to cultured pituitary cells collected from males at an early stage of development of the gonads, whereas basal levels and cell GtH content remained unchanged. The high pituitary response to $\mathrm{GnRH}$, observed in vitro (the present work) and in vivo at prespermiation and spermiation, could be due in part to the circulating levels of $11 \mathrm{KT}$ and $17 \alpha 20 \beta \mathrm{P}$ since a pretreatment with these steroids increases the GnRH-induced GtH release of cultures at the beginning of spermatogenesis. At prespermiation $17 \alpha 20 \beta \mathrm{P}$ tends to have a negative effect on the response to sGnRH of cultured gonadotrophs already primed by circulating levels whereas the effect of $11 \mathrm{KT}$ is not significant. This weak decrease in the response to $\mathrm{SGnRH}$, linked to the presence of $17 \alpha 20 \beta \mathrm{P}$ and the negative effect of $11 \mathrm{KT}$ on cell GtH content, might explain in part the slight decline in plasma GtH observed at the onset of spermiation (Sanchez-Rodriguez et al., 1978; Fostier et al., 1982). At spermiation 11KT was without effect on the pituitary response to $s G n R H$ while $17 \alpha 20 \beta P$ induced an increase in $\mathrm{GtH}$ released following the administration of $10^{-8} M$ sGnRH, cell GtH content being reduced. These two observations may explain the increase in plasma $\mathrm{GtH}$ observed at full spermiation observed after the initial decrease (Sanchez-Rodriguez et al., 1978).

An inhibiting action of the gonads on the hypothalamus-hypophysial axis in adult male rainbow trout is indicated by the increased plasma GtH following castration at various stages of spermatogenesis (Billard et al., 1976; Billard, 1978; Weil, 1981). However, the heterogeneity observed between individuals made it difficult to demonstrate a relationship with a variation in pituitary sensitivity to LHRH (Weil, 1981). Furthermore, the negative influence of gonads on hypothalamus-hypophysial axis was shown by recent data obtained on other species (winter flounder: Crim et al., 1987; cat fish: De Leeuw et al., 1987) by indicating an increase in the GnRH binding capacity following castration. The GnRH binding results following castration suggest that steroid treatments should decrease the response to GnRH of cultured gonadotrophs by decreasing binding to the receptors. However, the techniques used to study the retroaction of the gonads, castration and steroid pretreatment of pituitary cultures, are quite different. The effect of castration on plasma $\mathrm{GtH}$ is the sum of multiple effects on the hypothalamushypophysial axis and may include gonadal factors other than steroid ones since an inhibin-like factor is suspected in rainbow trout (Breton and Billard, 1980). Furthermore, following castration, circulating steroids are not completely abolished in rainbow trout as are total androgens (Schreck et al., 1972; Weil, 1981) and 11 KT in winter flounder (Crim et al., 1987); 17 $\alpha 20 \beta \mathrm{P}$ has not been studied but it is known that it is produced by other tissues such as the head kidneys (Sangalang and Freeman, 1988). Recent work, performed on rats, showed that a purified bovine inhibin decreased the number of GnRH receptors (Wang et al., 1988). In fish, the suppression of this factor by castration might suppress this inhibitory influence, inducing an increase in circulating GtH levels via an increase in GnRH receptor number.

We have demonstrated that $11 \mathrm{KT}$ and $17 \alpha 20 \beta P$ have a different effect on the pituitary response to $\mathrm{G} \mathrm{GRH}$, depending on the stages at which they are applied. Further work is necessary to determine the respective roles of other steroid and nonsteroid (inhibin-like) factors on the pituitary response to GnRH and on GnRH binding as soon as such an assay is available for this species.

\section{ACKNOWLEDGMENTS}

We extend our thanks to Dr. A. Fostier for helpful discussions and critical reading of the manuscript. This work was supported by a grant from Ministère de l'Education Nationale-Formation par la Recherche 
dans les disciplines agronomiques, agroalimentaires et biotechnologiques.

\section{REFERENCES}

Baynes, S. M., and Scott, A. P. (1985). Seasonal variations in parameters of milt production and in plasma concentration of sex steroids of male rainbow trout (Salmo gairdneri). Gen. Comp. Endocrinol. 57, 150-160.

Billard, R. (1978). Testicular feed back on the hypothalamo-pituitary axis in rainbow trout (Salmo gairdneri). Ann. Biol. Anim. Biachim. Biophys. 18, 813-818.

Billard, R., and Escaffre, A. M. (1975). Identification des stades de la spermatogenèse de la truite fario d'après la morphologie des gonades et la spermiation. Bull. Fr. Piscic. 256, 111-116.

Billard, R., Richard, M., and Breton, B. (1976). Stimulation de la sécrétion gonadotrope hypophysaire après castration chez la truite Arc-en-ciel; variation de la réponse au cours du cycle reproducteur. C.R. Acad. Sci. Paris, Ser. D 238, 171-174.

Breton, B., and Billard, R. (1980). Mise en évidence d'une régulation non stéroïdienne d'origine testiculaire sur la sécrétion d'hormone gonadotrope (GtH) chez la truite arc-en-ciel. C.R. Acad. Sci. Paris, Ser. D. 290, 1091-1094.

Breton, B., Fostier, A., Zohar, Y., Le Bail, P. Y., and Billard, R. (1983). Gonadotropine glycoproteique maturante et oestradiol-17ß pendant le cycle reproducteur chez la truite fario (Salmo truta) femelle. Gen. Comp. Endocrinol. 49, 220-231.

Campbell, C. M., Fostier, A., Jalabert, B., and Truscoot, B. (1980). Identification and quantification of steroids in the serum of rainbow trout during the spermiation and oocyte maturation. J. Endocrinol. 85, 371-378.

Crim, L. W., Wilson, C., St. Arnaud, R., Evans, D. M., and Harmin, S. A. (1987). Characteristics of fish pituitary LHRH receptors. In "Proceedings, Third Int. Symp. Fish Reprod. St John's Newfoundland."

De Leeuw, R., Beumer, P., Goos, H. J. Th., and Van Oordt, P. G. W. J. (1987). The effect of castration and steroid replacement on gonadotropinreleasing hormone ( $\mathrm{GnRH}$ ) receptor binding in the african catfish, Clarias gariepinus. In "Proceedings, Third Int. Sym. Fish Reprod. St John's, Newboundland."

Fostier, A., Billard, R., and Breton, B. (1984). Plasma 11-oxotestosterone and gonadotrophin in relation to the arrest of spermiation in rainbow trout (Salmo gairdneri). Gen. Comp. Endocrinol. 54, 378-381.

Fostier, A., Billard, R., Breton, B., Legendre, M., and
Marlot, S. (1982). Plasma 11-oxotestosterone and gonadotropin during the beginning of spermiation in rainbow trout (Salmo gairdneri). Gen. Comp. Endocrinol. 46, 428-434.

Lou, S. W., Aida, K., Hanyu, I., Sakai, K., Nomura, M., Tanaka, M., and Tazaki, S. (1986). Endocrine profiles in the males of a twice-annually spawning strain of rainbow trout, Salmo gairdneri. Gen. Comp. Endocrinol. 64, 212-219.

Sanchez-Rodriguez, M., Escaffre, A. M., Marlot, S., and Reinaud, $P$. (1978). The spermiation period in the rainbow trout (Salmo gairdneri) plasma gonadotropin and androgen levels, sperm production and biochemical changes in the seminal fluid. Ann. Biol. Anim. Biochim. Biophys. 18, 943-948.

Sangalang, G. B., and Freeman, H. C. (1988). In vitro biosynthesis of $17 \alpha, 20 \beta$-dihydroxy-4pregnen3-one by the ovaries, testes, and head kidney of the atlantic salmon Salmo salar. Gen. Comp. Endocrinol. 69, 406-415.

Schreck, C. B., Flickinger, S. A., and Hopwood, M. L. (1972). Plasma androgen levels in intact and castrate rainbow trout. Proc. Soc. Exp. Biol. Med. 140, 1009-1011.

Schulz, R. (1984). Serum levels of 11-oxotestosterone in male and $17 \beta$-estradiol in female rainbow trout (Salmo gairdneri) during the first reproductive cycle. Gen. Comp. Endocrinol. 56, 111-120.

Scott, A. P., and Baynes, S. M. (1982). Plasma levels of sex steroids in relation to ovulation and spermiation in rainbow trout (Salmo gairdneri). In "Proceedings of the International Symposium on Reproductive Physiology of Fish"' (C. J. J. Richter and H. J. Th. Goos, Eds.), pp. 103-106. Pudoc Wageningen.

Scott, A. P., and Sumpter, J. P. (1989). Seasonal variations in testicular germ cell stages and in plasma concentrations of sex steroids in male rainbow trout (Salmo gairdneri) maturing at 2 years old. Gen. Comp. Endocrinol. 73, 46-58.

Wang, Q. F., Farnworth, P. G., Findlay, J. K., and Burger, H. G. (1988). Effect of purified 31K Bovine Inhibin on the specific binding of gonadotropin-releasing hormone to rat anterior pituitary cells in culture. Endocrinology 123, 2161-2166.

Weil, C. (1981). "La fonction gonadotrope de l'hypophyse au cours du cycle sexuel chez deux poissons teléosteens la Carpe commune (Cyprinus carpio) et la truite arc-en-ciel (Salmo gairdneri), son contrôle par l'hypothalamus, les gonades et les facteurs externes. "Thèse de Doctorat d'Etat, Paris VI. Microfiche 870452 . Institut d'Ethnologie, Paris, 1987 (Archives et Documents-Microédition).

Weil, C., Billard, R., Breton, B., and Jalabert, B. 
(1978). Pituitary response to LH-RH at different stages of gametogenesis in the rainbow trout (Salmo gairdneri). Ann. Biol. Anim. Biochem. Biophy. 18, 863-869.

Weil, C., Hansen, P., Hyam, D., Le Gac, F., Breton, B., and Crim, L. W. (1986). Use of pituitary cells in primary culture to study the regulation of gonadotropin hormone $(\mathrm{GtH})$ secretion in rainbow trout: Setting up and validating the system as assessed by its responsiveness to mammalian and salmon gonadotropin releasing hormone. Gen. Comp. Endocrinol. 62, 202-209.

Weil, C., and Marcuzzi, O. (1990). Cultured pituitary cell response to $\mathrm{GnRH}$ at different stages of rainbow trout oogenesis and influence of steroid hormones. Gen. Comp. Endocrinol. 79, 483-491. 